BRAZILIAN JOURNAL

$\mathrm{OF}$

RADIATION SCIENCES

08-01B (2020) 01-09

\title{
Dose in biota due to alpha radionuclide emitters in a dam associated with a uranium mining
}

\author{
Pereira, W. ${ }^{\text {a, b}}$, Kelecom, A. ${ }^{\text {c }}$, Carmo, A. S. ${ }^{\text {b }}$ Campelo, E. L. C. ' , Charles- \\ Pierre, M. ${ }^{\text {, }}$ Souza, G. C. ${ }^{\text {d }}$ Padilha Filho, L. G. ${ }^{\text {b }}$, Lopes, J. M. ${ }^{\text {e, }}$ \\ ${ }^{a}$ Indústrias Nucleares do Brasil - INB, 27.555-000, Resende, RJ, Brasil \\ ${ }^{b}$ Universidade Federal do Rio de Janeiro - UFRJ, 21941-972, Rio de Janeiro, Brasil \\ ${ }^{c}$ Instituto de Biologia, Universidade Federal Fluminense - UFF, 24020-141, Niterói, RJ, Brasil \\ ${ }^{d}$ Universidade Veiga de Almeida - UVA, 20.271-020, Rio de Janeiro, RJ, Brasil,. \\ ${ }^{e}$ Instituto de Física, Universidade Federal da Bahia - UFBA, 40170-115, Salvador, Brasil \\ ${ }^{\text {f }}$ Programa de Pós-Graduação em Geoquímica (POSPETRO) - UFBA, 40170-110, Salvador, Brasil
}

pereiraws@gmail.com

\begin{abstract}
Radioprotection focuses on the protection of human beings, their descendants and the environment. In its 2007 recommendations, the International Commission on Radiological Protection - ICRP points to the need for radioprotection to be made in the environment, which was endorsed in 2014 by the International Atomic Energy Agency - IAEA, with a focus on biota. This study applies this methodology to assess the radiological risks from two species of fish who live the Águas Claras dam, situated in Caldas, MG, Brazil: traíra (Hoplias spp) and lambari (Astyanax spp). Three radionuclides were analyzed to measure these risks: ${ }^{238} \mathrm{U},{ }^{226} \mathrm{Ra}$ and ${ }^{232} \mathrm{Th}$. In terms of absorved dose rate, all the fish species analyzed in this study showed estimated values lower than the values from the literature, so that no relevant biological effects were expected.
\end{abstract}

Keywords: environmental radioprotection, biological effects in biota, uranium in fish, thorium in fish and radium in fish. 


\section{INTRODUCTION}

Ionizing radiation is a physical stressor that can cause damage with reasonably known mechanisms. The risks associated with radiation exposure can be assessed, quantified and prevented by measures that are already well established and widely accepted for humans. This acceptance has not been achieved for environmental radioprotection. This is mainly due to the limited attention historically given to environmental radioprotection, which, as a rule, has an anthropocentric view [13].

Radioprotection focuses on the protection of human beings and their descendants and the protection of the environment. Environmental protection has always been done indirectly through the protection of human being in the environment [1, 4].

This anthropocentric approach has several shortcomings. In its 2007 recommendation, the International Commission on Radiological Protection - ICRP [2] points to the need for radioprotection to be made in the environment, which was endorsed in 2014 by the International Atomic Energy Agency - IAEA [2-4], with a focus on biota [5-9].

For the calculation of dose in biota, ICRP propose the use of the concept of reference animal and plant - RAP [5], in line with the reference man of human radioprotection. Unlike human radioprotection, ICRP does not propose the concept of dose limit, but rather uses the concept of dose ranges. In common, all these projects and ICRP tend to protect populations rather than individuals and focus on the deterministic effects of radiation [5-9].

Regarding the environment, it was only in 2008 that the scope of protection of biota was clearly defined in publication No 108 [6], using the concept of animal and plant reference, applying the same concept of man reference, used in ICRP No 103 [2]. Protection of biota evolved with Publication No 114 in 2011 [7], with the definition of environmental parameters for dose calculation in biota, and in ICRP No 124 [8] with the formulation of environmental protection on different exposure situations. Dose conversion factors per AC unit were the focus with the ICRP Publication 136 [9].

As a branch of young science, there are still controversies to be discussed and evaluated to achieve a degree of understanding that is reflected in consensus on its recommendations. This study applies the methodology defined in ICRP Publications to assess the radiological risk, in terms of dose, as a criterion for assessing environmental radiological impact. 


\section{MATERIALS AND METHODS}

\subsection{Study area}

The Águas Claras dam (Figure 1) is located in Ribeirão das Antas river, County Caldas, Minas Gerais, Brazil. This dam was built to store water for the Ore Treatment Unit - OTU (uranium mine and processing plant).

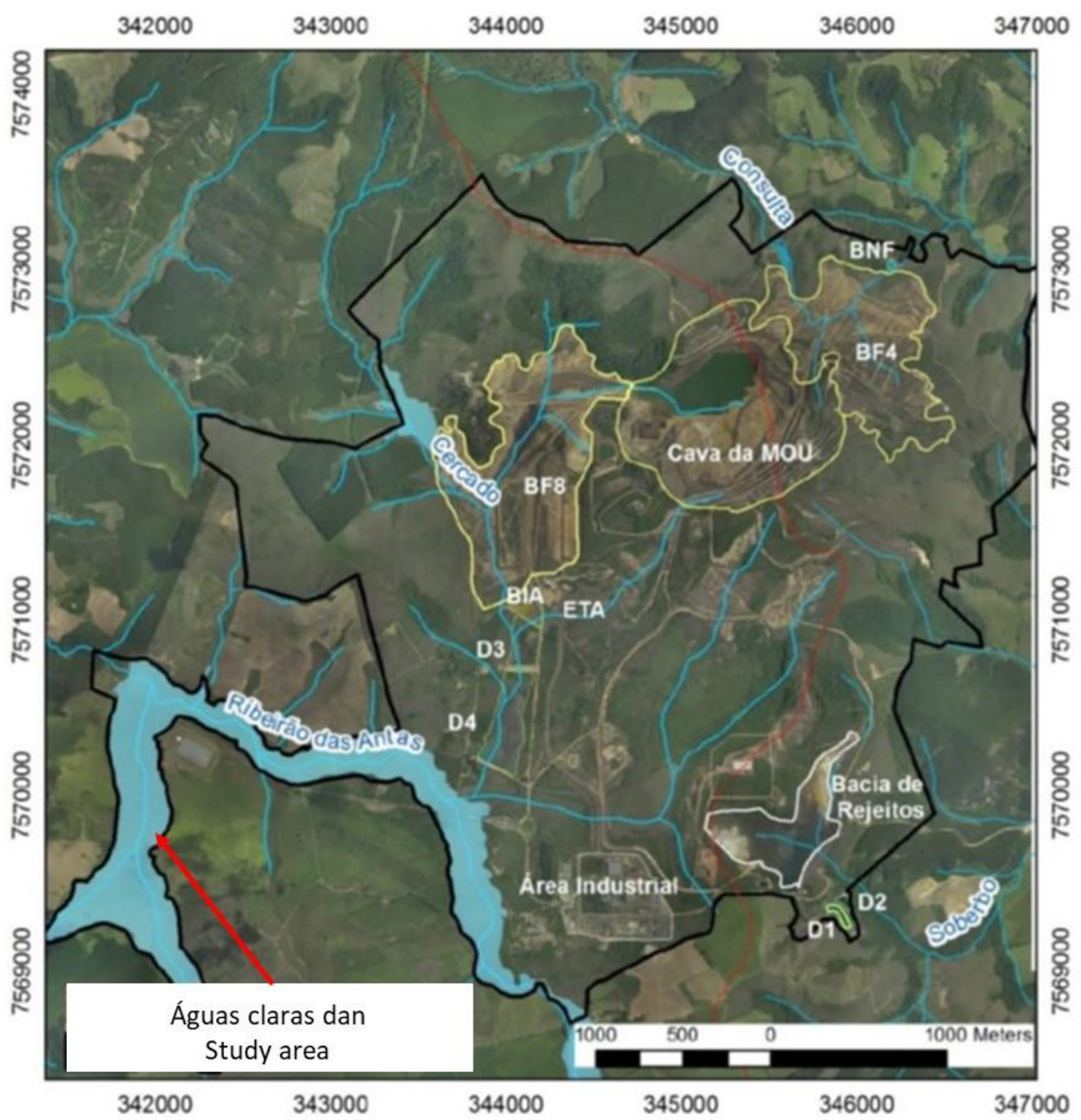

Figure 1. Location of Águas Claras dam in Ribeirão das Antas River and industrial area associated [10]. 


\subsection{Analyzed Species}

Two species of fish were analyzed: one of the carnivorous eating habit (Hoplias spp, vulgar name known as traíra, from the family Erythrinidae), and the other, of omnivorous eating habit (Astyanax spp, vulgar name as lambari, from the family Charcidae) which, due to its small size, serves as the food base of predators.

\subsection{Analyzed Radionuclides}

The long-lived alpha-emitting radionuclides, considered as critical, analyzed in this study were ${ }^{238} \mathrm{U},{ }^{226} \mathrm{Ra}$, from the uranium series [1] and ${ }^{232} \mathrm{Th}$, from the thorium series [1]. The samples were composed of a variable number of individuals, until reaching the minimum of $2 \mathrm{~kg}$ per sample. Two independent samples of each species were collected. The samples were concentrated by calcination to obtain light ash and, then, solubilized and analyzed. ${ }^{238} \mathrm{U}$ and ${ }^{232} \mathrm{Th}$ were analyzed by according with Savvin $[11,12]$; ${ }^{226} \mathrm{Ra}$ was analyzed by radiochemical separation followed by total alpha counting, according with Godoy et al [13]. Data were reported in $\mathrm{Bq} \mathrm{kg}^{-1}$ (wet mass).

\subsection{Dose rate estimation}

Dose rate estimation was performed according with the methodology proposed by ICRP in several recommendations, specially summarized in ICRP 136 [9]. The hourly dose rate estimate is based on equation 1 [9].

$$
\mathrm{DR}=\mathrm{AC} \cdot \mathrm{DC}
$$

where DR is the estimated absorbed dose rate in $\mu \mathrm{Gy} \mathrm{h}^{-1}, \mathrm{AC}$ is the activity concentration for the radionuclide in $\mathrm{Bq} \cdot \mathrm{kg}^{-1}$ (measured in this study) and DC is the dose coefficient, given by ICRP Publication 136 [9], in $\left(\mathrm{Bq} \mathrm{kg}^{-1}\right)\left(\mu \mathrm{Gy} \cdot \mathrm{h}^{-1}\right)^{-1}$ (see Table 01).

Table 1: Dose Coefficients for studied radionuclides in $\left[\left(\mathrm{Bq} \cdot \mathrm{kg}^{-1}\right) \cdot\left(\mu \mathrm{Gy} \cdot \mathrm{h}^{-1}\right)^{-1}\right]$, according to [9].

\begin{tabular}{lccc}
\hline Radionuclide & U-238 & Th-232 & Ra-226 \\
\hline Dose Coefficients & $2.50 \mathrm{E}-03$ & $2.70 \mathrm{E}-03$ & $1.50 \mathrm{E}-02$ \\
\hline
\end{tabular}




\subsection{Values for decision making}

To make a decision regarding the environmental impact assessment, based on the hourly dose rate, values capable of causing mortality, morbidity and reduced reproductive capacity were used, according with $[1,5]$, see Table 2 .

Table 2 : ICRP dose rate and biological effects [5].

\begin{tabular}{lc}
\hline Dose rate $\left(\mathbf{m G y ~ d}^{\mathbf{- 1}}\right)$ & Trout reference (freshwater fish) \\
\hline$>1.000$ & Embryo mortality \\
$100-1000$ & Potential increase in morbidity \\
& Some expected deleterious effects on young fish \\
$10-100$ & Reduction of resistance to infections \\
$1-10$ & Fertility reduction \\
$0,1-1$ & Potential reduction in reproductive success \\
$0,01-0,1$ & No information available \\
$<0,01$ & No information available \\
& Natural radiation \\
\hline
\end{tabular}

\section{RESULTS AND DISCUSSION}

For ${ }^{238} \mathrm{U}$, ACs ranged from 0.20 to $1.60 \mathrm{~Bq} \cdot \mathrm{kg}^{-1}$. For ${ }^{232} \mathrm{Th}$, the variation was between 0.02 and $0.30 \mathrm{~Bq} \cdot \mathrm{kg}^{-1}$. Finally, for ${ }^{226} \mathrm{Ra}$, the variation was between 0.07 and $1.40 \mathrm{~Bq} \cdot \mathrm{kg}^{-1}$ (see Table 02 , Figure 02). In terms of absorbed dose rate, the average value was around $10^{-2} \mu \mathrm{Gy} \cdot \mathrm{h}^{-1}$ for the four samples (see Table 03, Figure 03).

Table 2. Activity concentration of alpha emitting radionuclides in studied fishes in $\mathrm{Bq} \cdot \mathrm{kg}^{-1}$.

\begin{tabular}{lccc}
\hline \multirow{2}{*}{ SAMPLES } & \multicolumn{3}{c}{ Radionuclides } \\
\cline { 2 - 4 } & $\mathbf{U - 2 3 8}$ & Th-232 & Ra-226 \\
\hline Traíra & $2.09 \mathrm{E}-01$ & $3.50 \mathrm{E}-02$ & $6.38 \mathrm{E}-02$ \\
Traíra & $1.72 \mathrm{E}-01$ & $1.94 \mathrm{E}-02$ & $7.94 \mathrm{E}-02$ \\
Lambari & $6.35 \mathrm{E}-01$ & $4.06 \mathrm{E}-02$ & $5.82 \mathrm{E}-01$ \\
Lambari & $1.57 \mathrm{E}+00$ & $2.88 \mathrm{E}-01$ & $1.42 \mathrm{E}+00$ \\
\hline
\end{tabular}




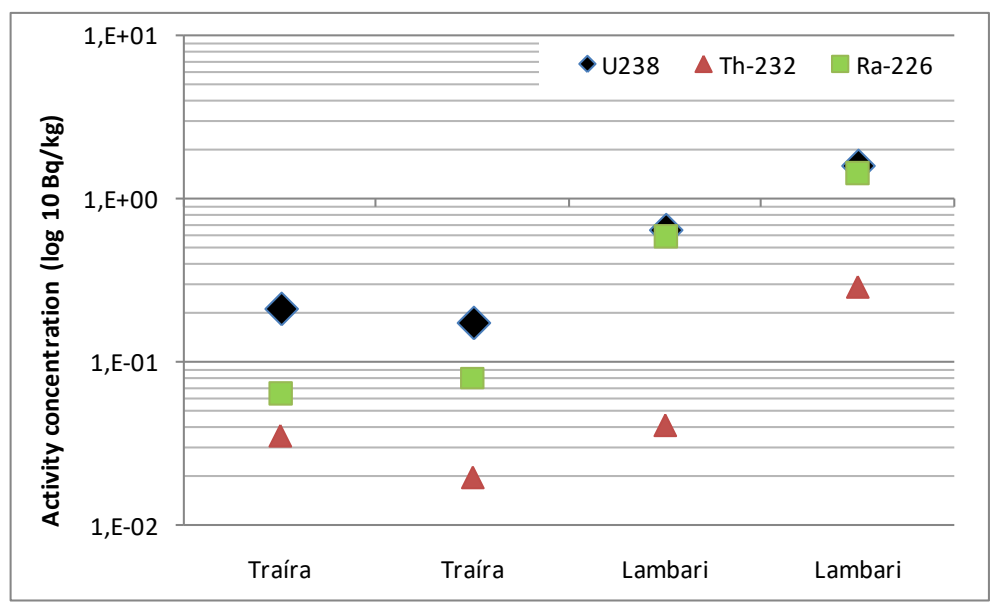

Figure 2. Activity concentrations of alpha emitting radionuclides, in log $10\left(\mathrm{~Bq} \cdot \mathrm{kg}^{-1}\right)$.

Table 3. Dose rate, in $\mu \mathrm{Gy} \cdot \mathrm{h}^{-1}$, due to the alpha emitters, in the studied fishes.

\begin{tabular}{lcccc}
\hline \multirow{2}{*}{ SAMPLES } & \multicolumn{3}{c}{ Radionuclide } & \multirow{2}{*}{ Total } \\
\cline { 2 - 4 } & $\mathbf{U - 2 3 8}$ & Th-232 & Ra-226 & \\
\hline Traíra & $5.23 \mathrm{E}-04$ & $9.45 \mathrm{E}-05$ & $9.57 \mathrm{E}-04$ & $1.57 \mathrm{E}-03$ \\
Traíra & $4.29 \mathrm{E}-04$ & $5.24 \mathrm{E}-05$ & $1.19 \mathrm{E}-03$ & $1.67 \mathrm{E}-03$ \\
Lambari & $1.59 \mathrm{E}-03$ & $1.10 \mathrm{E}-04$ & $8.73 \mathrm{E}-03$ & $1.04 \mathrm{E}-02$ \\
Lambari & $3.93 \mathrm{E}-03$ & $7.78 \mathrm{E}-04$ & $2.13 \mathrm{E}-02$ & $2.60 \mathrm{E}-02$ \\
\hline
\end{tabular}

Dose rate average

9.92E-03

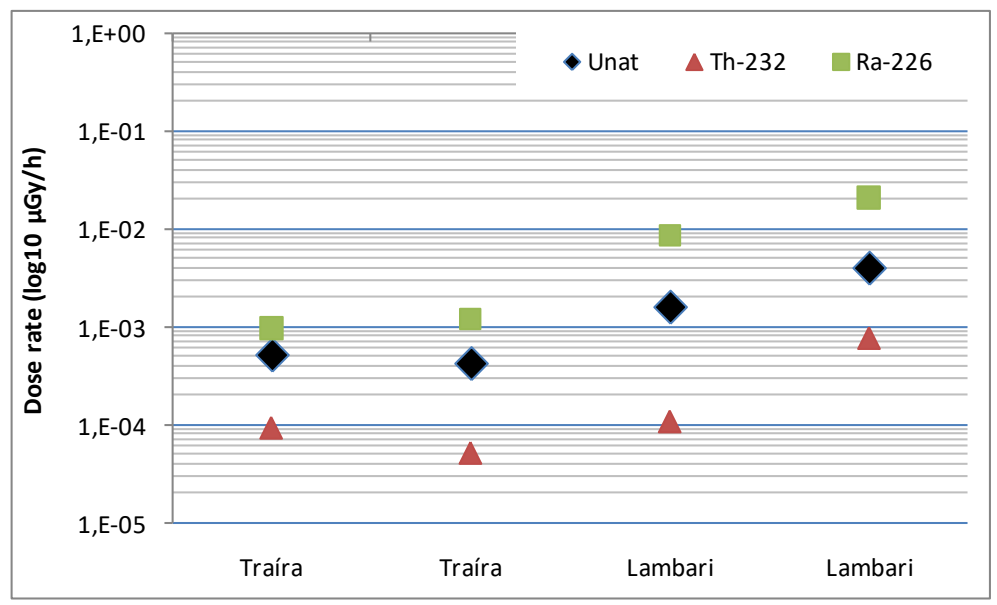

Figure 03. Dose rates of alpha emitting radionuclides, in $\log 10(\mu G y / h)$. 


\section{CONCLUSIONS}

The analysis of the data showed that, even though it is associated with uranium mining and the Águas Claras Basin is an effluent release path, the analyzed fishes in this basin presented bioaccumulation of alpha radionuclides emitting a maximum of $1.4 \mathrm{~Bq} \mathrm{~kg}^{-1}$, values lower than that found in marine fishes [1, 14-15]. Likewise, this maximum value is below that found for freshwater fish [5-7]. Based on the ICRP model [9], the doses generated by these AC estimated average internal doses of alpha emitters below $0.01 \mu \mathrm{Gy} \cdot \mathrm{h}^{-1}$, below $0.1 \mathrm{mGy} \mathrm{d}^{-1}$, values that allow the first detectable biological effects to be verified in fishes.

Based on the analysis carried out, we can infer that the biota of benthic fishes from the Águas Claras dam is exposed to natural alpha emitters radionuclides compatible with the worldwide Background estimated by the ICRP for freshwater fishes [5-7], generating doses that do not allow estimating biological impact in the evaluated fishes population, which are at different trophic levels (traíra carnivore and lambari - omnivore). Based on this analysis, the environmental radiological impact generated by the installation is within the permissible impact, with no radiological risk to the analyzed benthic fishes' population.

\section{REFERENCES}

[1] Pereira, W. S. (2010). O cálculo de dose na biota como ferramenta de radioproteção ambiental. Niteroi: UFF. D. Sc. Thesis, in portuguese.

[2] ICRP - International Commission on Radiological Protection. Recommendations of the International Commission on Radiological Protection, n 103. 2007, New york: Elsevier Science.

[3] IAEA - International Atomic Energy Agency. Radiation Protection and Safety of Radiation Sources: International Basic Safety Standards General Safety Requirements Part 3 No. GSR Part 3 471 . 2014, Vienna, Austria: IAEA. 
[4] CNEN - Nacional Commission for Nuclear Energy, Norm CNEN-NN-3.01, Basic Guidelines for Radiological Protection, 2014, pp. 34.

[5] ICRP - International Commission on Radiological Protection, A Framework for Assessing the Impact of Ionising Radiation on Non-human Species. ICRP Publication 91. Ann. ICRP 33 (3).

[6] ICRP - International Commission on Radiological Protection, Environmental Protection - the Concept and Use of Reference Animals and Plants. ICRP Publication 108. Ann. ICRP 38 (46), 2008..

[7] ICRP - International Commission on Radiological Protection, Environmental Protection: Transfer Parameters for Reference Animals and Plants. ICRP Publication 114, Ann. ICRP 39(6), 2009.

[8] ICRP - International Commission on Radiological Protection, Protection of the Environment under Different Exposure Situations. ICRP Publication 124. Ann. ICRP 43(1), 2014..

[9] ICRP - International Commission on Radiological Protection, Dose coefficients for nonhuman biota environmentally exposed to radiation. ICRP Publication 136. Ann. ICRP 46(2), 2017.

[10] Alberti, H. L. C.; Estudo hidroquímico e isotópico das águas subterrâneas impactadas pela drenagem ácida da mina de urânio - Osamu Utsumi, planalto de Poços de Caldas (MG), 198 pp. tese de doutorado em geociências, UNICAMP, CAMPINAS, 2017, http://repositorio.unicamp.br/jspui/handle/REPOSIP/330982

[11] Savvin, S. B. (1961). Analytical use of arsenazo III: Determination of thorium, zirconium, uranium and rare earth elements. Talanta, 8 (9), 673 -685. https://doi.org/10.1016/0039$\underline{9140(61) 80164-1}$

[12] Savvin, S. B. (1964). Analytical applications of arsenazo III-II: determination of thorium, uranium, protactinium, neptunium, hafnium and scandium. Talanta, 11 (1), 1-6. https://doi.org/10.1016/0039-9140(64)80003-5

[13] Godoy, J. M., Lauria, D. C., Godoy, M., Cunha, R. (1994).Development of a sequential method for determination of ${ }^{238} \mathrm{U},{ }^{234} \mathrm{U},{ }^{232} \mathrm{Th},{ }^{230} \mathrm{Th},{ }^{228} \mathrm{Th},{ }^{228} \mathrm{Ra},{ }^{226} \mathrm{Ra}$ and ${ }^{210} \mathrm{~Pb}$ in environmental samples. J. Radioanal. Nucl. Chem., 182 (1), 165-169. https://doi.org/10.1007/BF02047980 
[14] Pereira, W. S., Kelecom, A and Py Júnior.D. A., Activity of natural radionuclides and their contribution to the absorbed dose in the fish cubera snapper (Lutjanus cyanopterus, Cuvier, 1828) on the coast of ceará, Brazil, BRAZILIAN JOURNAL OF OCEANOGRAPHY, 58(special issue IICBBM):25-32, 2010.

[15] Carmo, A. S, (2019), Descarga de efluentes líquidos contendo radionuclídeos em uma instalação de medicina nuclear e seus impactos no meio ambiente, D. Sc thesis, Nuclear Eng., COPPE/UFRJ, 2019. 